\title{
ELL wt Allele
}

National Cancer Institute

\section{Source}

National Cancer Institute. ELL wt Allele. NCI Thesaurus. Code C97517.

Human ELL wild-type allele is located in the vicinity of $19 p 13.1$ and is approximately $79 \mathrm{~kb}$ in length. This allele, which encodes RNA polymerase II elong ation factor ELL protein, plays a role in the elongation of transcribed RNA. A chromosomal translocation $\mathrm{t}(11 ; 19)$ (q23;p13.1) of this gene and the MLL gene is associated with acute myeloid leukemia. 